\section{Population Statistics}

THE National Institute of Economic and Social Research is planning the issue of Occasional Papers to make quickly available the results of research which are of particular current interest. The first to be issued deals with "The New Population Statistics" and has been written by R. R. Kuczynski, a leading authority on the subject of population. The paper is a critical review of a memorandum presented by the Registrar-General to the Royal Commission on the Geographical Distribution of the Industrial Population more than three years ago but only recently made public. The author bases his criticism on a searching analysis of certain new fertility data collected under the Population (Statistics) Act of 1938, published this year in the Registrar-General's Statistical Review of England and Wales for 1938 (Tables, Part II, Civil), to which all students of population problems had been looking forward eagerly.

The study is divided into four short chapters. In the first two, Dr. Kuczynski discusses the new data and some of the results which may be deduced from them. In the last two he attacks the forecasts of the future population of Great Britain made by the Registrar-General and the remedies he proposes for them. The position, as the author sees it, is concisely stated in the final paragraph, which deserves quotation: "It would be most regrettable if the Registrar-General's conclusions should induce the general public to believe that the prevention of a population decline is an easy matter which can be achieved any time by very simple and immediately effective means. It is now more important than ever to realize that Britain's population problem is a serious problem and extremely difficult to solve. Fortunately, the new population statistics, if perused judicially, will somewhat facilitate that task."

\section{Geology of the U.S.S.R.}

AccordING to the Soviet War News, reports from the Geological Committee of the Council of People's Commissars indicate that more than two thousand expeditions went out during the summer, and discovered valuable new deposits of strategic raw materials. A feature of war-time geology is that the exploitation of new deposits begins much earlier than it did in peace-time. New deposits of aluminium ores have been discovered in the Urals, in Western and Eastern Siberia, and also in Kazakhstan. The exploitation of newly discovered antimony and mercury deposits has already begun. Rich sources of iron ore, fluxes and fireproof minerals for the iron and steel industry have been opened up in the Urals, Siberia and the Central Asian Republics. Prospecting for combustible shales is meeting with success in the Urals and Eastern Siberia. Particularly important, from the point of view of defence, is the discovery of new sources of manganese. Several new manganese mines are already functioning in the Urals, Western Siberia and Kazakhstan. During seven months of 1942 the output of manganese ore in these regions was 250 per cent greater than in the parallel period of 1941 .

Coal mines are being developed in the immediate vicinity of the Urals iron and steel industries. More than ten coal pits have been sunk in the recently discovered deposit in the middle of the Kizelovo district, and are already in production. An exhibition of the mineral wealth of Tadjikistan, the Soviet Republic north of Afghanistan, opened in Stalinabad, contains a collection of seventy specimens of useful minerals recently discovered in the Pamirs and in the mountains of Gissar and Zeravshan; among them are iron ore, tin, wolfram and lead.

\section{The Leningrad Botanical Institute}

THE Leningrad Botanical Institute, the largest in the U.S.S.R., has not suspended its work under conditions of war and siege. The Institute has a rich botanical collection of some seven million specimens of plants. Its library contains 135,000 volumes on botany, while more than 20,000 specimens of plants from all parts of the world are to be found in its gardens laid out about 230 years ago on the order of Peter the Great. The hothouses alone of the Institute occupy an area of 35,000 square metres.

During the autumn of 1941,193 scientific research workers and employees of the Institute remained in the city in order to preserve this valuable property, and not only did they preserve it under the very difficult conditions of the past winter but they also continued their scientific research work. While the Germans were shelling the city Prof. Rozhevits completed his monograph entitled "The Biology and the Economic Importance of the World's Cereal Plants".

\section{Official Recommendation of Insecticides and Fungi- cides}

WrTH the concurrence of the Agricultural Improvement Council, a scheme under which official approval can be given to proprietary insecticides and fungicides for the control of plant pests and diseases has now been agreed by the Agricultural Departments of Great Britain and the Association of British Insecticide Manufacturers. The Minister of Agriculture and Fisheries and the Secretary of State for Scotland in consultation with the Agricultural Research Council, have appointed the following Committee to advise on applications from manufacturers for the approval of their products under this scheme: Prof. J. W. Munro (chairman), Dr. C. E. Foister, Mr. C. T. Gimingham, Mr. A. J. Holden, Dr. Hubert Martin, Mr. W. C. Moore, Dr. D. D. Pratt, Dr. H. Shaw, Dr. J. T. Martin (secretary). This Committee will be responsible for recommending approval. The principles and conditions of approval for the various groups of products will be drawn up by a joint panel composed of the members of the Committee, together with four representatives of the Association of British Insecticide Manufacturers, a representative of the Government Chemist and a representative of the Agricultural Research Council. This Joint Panel will also consider any points of principle arising out of particular products submitted for approval. Particulars of the scheme may be obtained from the Secretary of the Committee, Plant Pathological Laboratory, Ministry of Agriculture, Milton Road, Harpenden, Herts.

\section{Study of the Atomic Nucleus}

The University of Manchester branch of the Association of Scientific Workers has organized a series of lectures which are being given by scientific men engaged in research. The lectures are to cover various scientific topies, and it is hoped that they may help to establish contacts between scientific men working in widely different fields. Lectures have been given on "Relativity", "Heredity" and "Organic Chemistry". A meeting on October 14 was addressed by Dr. S. Tolansky on "The Study 